\title{
Macquarie University
}

\author{
Hsu-Ming Teo
}

\section{History, the Holocaust and children's historical fiction}

\begin{abstract}
:
In 2013, the NSW Premier's Young People's History Prize was won by Australian novelist Jackie French's historical novel Pennies for Hitler. French's young adult novel, Dingo: The dog who conquered a continent, was also one of the three works shortlisted for the prize. No history/literary wars broke out over these historical novels. This article considers why children's historical fiction is considered 'good' (or 'good enough') history when so many adult historical novels are not. Beginning with a brief overview of the competing claims about the 'fictiveness' of history, this article then uses French's Pennies for Hitler as well as her novel Hitler's daughter (1999) as case studies to test what Australian children - French's main readership - would actually learn about Nazi Germany, the Holocaust and the Second World War from historical fiction. It concludes with a reflection about why the pleasures of childhood reading are denied adults, who are perhaps encouraged to treat history like work instead.
\end{abstract}

\section{Biographical note:}

Hsu-Ming Teo is a novelist and cultural historian based in Macquarie University, Australia. Her academic publications include Desert passions: Orientalism and romance novels (2012), Cultural history in Australia (2003), and range of articles and book chapters on the history of Orientalism, travel, British imperialism, fiction, and popular culture. She is an associate editor of the Journal of Popular Romance Studies and an editorial board member of the Journal of Australian Studies and the Australasian Journal of Popular Culture. Her first novel Love and vertigo (2000) won The Australian/Vogel Literary Award and her second novel Behind the moon (2005) was shortlisted for the New South Wales Premier's Literary Awards. A judge of the 2013 New South Wales Premier's Young People's History Prize, she is currently working on an edited project on the popular culture of romantic love in Australia and researching representations of the Holocaust in popular fiction.

Keywords:

Children's historical fiction - The Holocaust - History 
In 2013 the New South Wales Premier's Young People's History Prize was awarded to the Australian novelist Jackie French for her historical novel Pennies for Hitler (2012): a simple story about the part-Jewish son of an English academic living in Germany who, in 1939, is forced to flee to war-torn London and, from thence, to seek refuge in wartime rural Australia. This was not the first time French had won a history prize for her fiction. Previously, her novel The night they stormed Eureka (2009) had won the 2010 Young People's History Prize, while her novel They came on Viking ships (2005) had been shortlisted for the same prize in 2006. The unusual thing about the 2013 prize was that another of French's young adult novels, Dingo: The dog who conquered a continent, was also one of the three entries shortlisted that year. Then in 2014, French's novel The road to Gundagai was shortlisted for the same prize. In all this time, no history/literary wars broke out over whether these historical novels could legitimately be considered history (unlike the stoush between academic historians and Kate Grenville over The secret river). Established in 1997, the NSW Premier's History Awards are intended 'to honour distinguished achievement in history by Australian citizens and permanent residents' and to 'assist in establishing values and standards in historical research and publication and encourage everyone to appreciate and learn from the work of our historians' (NSW State Library 2014). In no other category apart from the Young People's History Prize is fiction considered eligible for these awards. Young people are clearly given a great deal more latitude with regard to the type of histories they consume; the Young People's History Prize is for a work that simply 'increases the understanding and appreciation of history by children and young adults' (NSW State Library 2014).

There is a striking disjunction in discussions about adult historical fiction and children's historical fiction. A double standard is clearly at play here, where adults are expected to consume 'serious' history written by historians whereas judges consider novels a suitable vehicle for children to learn history. Children must be entertained with a good plot and absorbing characters in order to be interested in history, whereas entertainment is incidental (although no doubt much appreciated) for adult readers. Rigorous historical methodology, complexity or sophistication of historical argument, contribution to new knowledge and erudition are fundamental requirements for histories that adults read, but not for young people. Instead, entries merely need to 'be based on sound historical research and encourage further exploration of the past' (NSW State Library 2014).

This article considers why children's historical fiction is considered 'good' (or 'good enough') history when so many adult historical novels are not. It begins with a brief overview of the competing claims about the fictiveness of history put forward by poststructuralist theorists and historiographers, and why historians and many (though not all) novelists have rejected these claims. It then outlines the arguments presented by educationists about why historical fiction can be an effective tool to teach children history, historical concepts and historical methodology. Concerns over postmodernist attacks on history as a discipline, based largely on how history is consciously crafted through writing, often coalesce around the issue of whether such attacks undermine the historicity of the Holocaust and contribute to Holocaust denial (see Evans 1999 
and Ginzburg 1992 on Hayden White's Metahistory and Holocaust-denier Robert Faurisson). Historical fiction referring to the Holocaust feeds into this debate because concerns are also raised about whether such novels contribute to the fictionalising of the Holocaust. Scholars and Holocaust survivors worry about whether readers' knowledge will come only from the novels they read, thus contributing to a fundamental misunderstanding of the nature and events of the Holocaust, and they debate whether it is ethical to represent the Holocaust in fiction, thereby transforming suffering into art (Vice 2000: 1-4). There is again a disjunction in social standards and scholarly commentary over Holocaust fiction for adults and that for children, for these concerns do not appear to apply to children's fiction drawing upon the history of the Holocaust.

This essay uses French's Pennies for Hitler as well as her earlier novel Hitler's daughter (1999) as case studies to test what Australian children - French's main readership - would actually learn about Nazi Germany, the Holocaust, and the Second World War from historical fiction. The essay concludes with an evaluation of French's novels using the current scholarship on children's fiction about the Holocaust as well as readers' reviews of these novels as history. The choice of these two novels is precisely because French is one of the finest and most widely lauded Australian authors writing children's historical fiction today, and these two novels refer extensively to the Holocaust and the ethical issues it raises. Discussion of the Holocaust crops up repeatedly in Hitler's daughter, in which a group of rural Australian children in some indeterminate era learn about the Holocaust through storytelling, at school, and in conversation with parents. In Pennies for Hitler, the Holocaust is the plot device which frames the narrative trajectory and character development of the main protagonist of the novel, even though the novel also treats other aspects of mid-twentieth century history such as London during the Second World War, the evacuation of children, child immigrants to Australia, and rural Australian society during the war. Given the point previously made about how the Holocaust has become central to debates about whether historical fiction is useful for transmitting historical knowledge and understanding or whether it contributes to the fictionalising of the Holocaust, I will focus only on the plot aspects of French's novels that deal specifically with Holocaust history. I am using Yad Vashem's ${ }^{1}$ definition of the Holocaust as

the sum total of all anti-Jewish actions carried out by the Nazi regime between 1933 and 1945: from stripping the German Jews of their legal and economic status in the 1930s; segregating and starvation in the various occupied countries; the murder of close to six million Jews in Europe (Yad Vashem 2015).

\section{History, fiction and the Holocaust}

The fundamental tenets of the postmodern attack on history as a discipline - with its claims to represent and interpret the past with varying degrees of accuracy - are quite well-known by now. Stripped of arcane jargon, the argument that history differs little from fiction is as follows. According to Hayden White (1973), Keith Jenkins (1991) 
and their followers, history is not an objective, scientific or infallibly true account of the past because it depends on written sources that were created from the imperfect and selective memories of their authors. The entirety of the past cannot be captured by those who documented it firsthand, so all that is left of the past are skewed and sketchy accounts - individually biased autobiographies, memoirs, diaries, reports of events, chronicles and so forth - that are constructed employing the same narrative techniques used to create fiction. From these problematic scraps of sources that historians manage to find, historians then select evidence that fits a story they want to tell about the past; a story that is shaped by their own assumptions and ideological leanings, and that is plotted in the same way that a fictional story is plotted, according to particular genres (for example Northrop Frye's [1957] literary archetypes of comedy, romance, tragedy or irony) and using many of the same rhetorical devices that fiction writers use to create narratives.

The gap between the past and the history that the historian wants to reconstruct is therefore unbridgeable because of: 1) the unreliability of biased eyewitness accounts of events and memories of the past; and 2) the process of writing - whether writing primary sources or writing history - which uses narrative techniques to arrange or plot a story about the past; a past that can be arranged or plotted in many different ways, and according to many different perspectives. It is thus epistemologically impossible to reach a consensus about the past, let alone the 'truth' of the past, because history is a matter of competing genres relying on skewed sources. In the words of Hayden White, historical accounts are simply 'verbal fictions, the contents of which are as much invented as found and the forms of which have more in common with their counterparts in literature than they have with those in the sciences' (White 1978: 82, original emphasis). For poststructuralist theorists and literary historiographers, postmodern historical fiction - especially the subgenre of "postmodern historiographic metafiction' (Hutcheon 1988) - is preferable to history because it is more honest about its fictiveness and the artifice of its construction, more aware of the unreliability of its sources, and more open about the power-plays behind the creation of narratives about the past; a self-serving past that is created for the benefit of particular groups or communities (see Parrish 2008 and Southgate 2009).

Many historians acknowledge that history writing is a literary endeavour that does include fictive aspects. Indeed, as Ann Curthoys and John Docker show, history and fiction have been tightly interlocked enterprises 'at the very birth of historical writing itself' (2010: 6). Curthoys and Docker argue that Herodotus and Thucydides, two of the earliest known historians whose works are still extant, 'established the curious doubleness of history: history as a sustained inquiry into the past; history as literary, engaged in narrative, history as drama, engaged in the creation of scenes, characters, and speeches' (13). Historians, however, reject the nihilistic conclusion that just because archival sources are flawed and historical accounts are provisional constructions of the past and subject to re-interpretation or revision, it is therefore not worth investigating the past because we can never know anything about it - a position that Jenkins has now reached (Macfie 2012). However problematic, the records of the past do convey something about lives once lived. 
This is a conviction held by most novelists as well as historians, for otherwise, novelists of historical fiction - 'literary' novelists such as Kate Grenville, Thomas Keneally and Ian McEwan, for instance, or mass-market fiction writers such as Tim Willocks, Paul Fraser Collard and Glyn Iliffe ('Writing historical novels') - would not bother spending countless hours delving in the archives to recreate the past. They would simply make it up and not concern themselves as to whether their fictional worlds align with or faithfully represent what we are able to glean from the past. It is, in fact, the sheer effort of historical research - reading both archival material and historians' works - that novelists put into their fiction that persuades certain educationists such as Evelyn Freeman (1988), Alun Hicks and Dave Martin (1997), Donna Norton (1999) and Sarah Herz (2010) that historical fiction can be fruitfully employed to teach history to reluctant students.

In Australia, Grant Rodwell is one of the most enthusiastic proponents of the value of using children's historical fiction to educate young people about the past. Rodwell's book Whose history: Engaging history students through historical fiction (2013) begins with an anecdote about Jackie French addressing the History Teachers Association of Australia conference in 2010. Rodwell argues that the fact that an award-winning children's novelist was invited to give a keynote lecture to the HTAA shows that 'Australian teachers of History are recognising the value of the historical novel as a pedagogical strategy in the History classroom' (7). For Rodwell, historical fiction is an important conduit of knowledge about the past because 'children are very poorly engaged with the study of History in Australian schools' (10). Reading historical fiction teaches children to understand historical development and change over time in a way that is absorbing because they connect and empathise with characters in the historical novel; they care what happens to these characters and, because of this engagement, they are willing to understand the historical context that shapes these characters' lives. By empathising with characters in a historical novel, students learn to use their imagination to conjecture what the past might have been like. Thus:

Historical fiction can help students understand what happened in the past (what people did at the time of the event, specific actions taken, and so on), why the event took place (what the actions, beliefs, motivations and intentions of certain actors were), and the consequences of the event (how people were affected, how they responded, and so on). Historical fiction also can help students understand broader contexts, such as the social forces created and shaped by people, or the ways certain economic conditions affected people's lives. Historical fiction, moreover, can make visible the contributions of individuals and groups of people often marginalised by traditional heroes and great (military) leaders' accounts of history ... [H]istorical fiction, because of its multiple characters and perspectives, also can better provide voice to those who might have been silenced or adversely affected by a particular event, thus inviting students to question why some groups had less power, influence, or privilege than others (41).

On the one hand, the view that historical fiction is no more and no less capable of informing young people about the past - and probably a lot more engaging and effective at it than history books - is consonant in some ways with the 
poststructuralist view that there is little difference between history and fiction. It sits uncomfortably with historians' conviction that however much research the novelist has done, historical fiction is nonetheless distinct from history because the novelist is still making things up, creating characters, conversations, thoughts, motives and events that cannot possibly be verified. On the other hand, the faith among educationists that there is indeed a past that is accessible to a certain degree recoverable through its remnants and constructed by historians working towards a reasonably accurate understanding of it - is distinctly at odds with the poststructuralist critics' belief that the past remains wholly inaccessible and that the works of historians are of little value in informing us about it. These beliefs among educationists, shared by children's authors such as French, explain why historical fiction continues to be submitted as works of history for the Young People's prize and why a novel about the Holocaust - perhaps the most contentious of all topics for historical fiction - can even win.

For the western world, there are few topics with more historical gravitas accompanied by more soul-searching than the Holocaust. Representations of the Holocaust have been problematic ever since Theodor Adorno opined that 'to write a poem after Auschwitz is barbaric' (1967: 34). Holocaust survivors such as Elie Wiesel or the documentary filmmaker Claude Lanzmann express the view that it is ultimately impossible to explain the Holocaust or represent it adequately. In Wiesel's words, 'just as no one could imagine Auschwitz before Auschwitz, no one can now retell Auschwitz after Auschwitz. ... Only those who lived it in their flesh and in their minds can possibly transform their experience into knowledge' (cited in Vice 2000: 5). Indeed, for Wiesel the very quest for knowledge itself is tainted; to draw parallels in ordinary human experience with the extreme fear, pain, suffering, hunger, cold and so forth of those who lived through the Holocaust, and to imagine that we can put ourselves in their shoes and understand what it must have been like, simply misrepresents and diminishes the experiences of Holocaust victims and survivors. Wiesel believes that this quest is, possibly, even a ploy to turn the page on Holocaust history: 'We want to know, to understand, so we can turn the page: is that not true? So we can say to ourselves: the matter is closed and everything is back in order' (1995: 144). Those who maintain that the Holocaust is ultimately ineffable and beyond comprehension argue that we can never fully understand why the Holocaust occurred; to attempt to do so may range us with the perspective of the perpetrators (Lanzmann 1995: 207).

If historical explanations are problematic and always incomplete, fictive or fictional representations are deemed even more ethically questionable. The issue here, as Lawrence Langer observes, is whether art can 'represent the inexpressibly inhuman suffering of the victims, without doing an injustice to that suffering'. For art to impose meaning on, or create meaning out of, the Holocaust seems 'disagreeable, almost dishonorable' since it implies that 'the inconceivable fate of the victims appears to have had some sense after all' (1975: 1). The belief in the almost-sacred, incommunicable nature of the Holocaust is what the philosopher Gillian Rose has bitingly dubbed 'Holocaust piety'; an attitude that approaches the Holocaust with 
'silence, prayer, the banishment equally of poetry and knowledge, in short, the witness of ineffability' at the expense of understanding. The resort to claims that the Holocaust can never be thoroughly understood or convincingly portrayed can serve as an excuse not even to make the attempt, perhaps because 'we fear that it may be all too understandable, all too continuous with what we are - human, all too human' (Rose 1996: 43).

Despite the strictures against representation, however, novelists have written - even over-written - about the Holocaust, to the point where Yosef Hayim Yerushalmi commented in 1982: 'the Holocaust has already engendered more historical research than any single event in Jewish history, but I have no doubt whatever that its image is being shaped, not at the historian's anvil, but in the novelist's crucible' (98). Critical attention has turned accordingly to the literary representation of the Holocaust, a representation that is highly self-conscious and bound by the following set of prescriptions or sacred rules:

1. The Holocaust shall be represented, in its totality, as a unique event, as a special case and kingdom of its own, above and below or apart from history.

2. Representations of the Holocaust shall be as accurate and faithful as possible to the facts and conditions of the event, without change or manipulation for any reason artistic reasons included.

3. The Holocaust shall be approached as a solemn and even sacred event, with a seriousness admitting no response that might obscure its enormity or dishonor its dead (Des Pres 1988: 217).

To this list, Lydia Kokkola has added: '4. We must not forget. 5. All writing about the Holocaust should adopt an ethical position that fosters resistance to fascist philosophy' (2003: Location 342).

Terrence Des Pres calls this list of rules 'Holocaust etiquette': the belief that 'anything pertaining to the Holocaust must be serious, must be reverential in a manner that acknowledges the sacredness of its occasion' (1988: 218). Most of these Holocaust narratives are in the realist mode of representation and many, especially in popular culture - whether books and/or films like The diary of Anne Frank, Schindler's list or The boy in the striped pyjamas - incorporate a narrative of sacrifice and redemption that confers meaning upon individual experiences of the Holocaust, trumpeting a message of the ultimate triumph of good over evil which militates against the overall history of the Holocaust. Such narratives of redemption have sometimes been included in the phenomenon known as the 'Americanization of the Holocaust', described by Alvin Rosenfeld as a move to 'downplay or deny the dark and brutal sides of life and to place a preponderant emphasis on the saving power of individual moral conduct' (1997: 123).

Critics have reacted harshly towards realist and redemptory fictional narratives of the Holocaust, often panning the anodyne bourgeois sentimentality of such narratives. As if in recognition of the difficulties of adequately representing the Holocaust, critics are suspicious of fiction that is too pleasurable or too easy to read. Instead, what is preferred are difficult texts and more avant-garde experimental aesthetics that disturb, 
unsettle and are 'unaccommodating to the reader' because these may well 'be more successful in conveying the disruption and unease that the subject demands than more seamless, aesthetically pleasing work' (Vice 2000: 161). Easy-to-read works that engender reader empathy seem to be the problem. Even works that aim to shock and offend with their seeming 'bad taste', what Matthew Boswell calls 'Holocaust impiety' - representations of the Holocaust that are kitsch, irreverent, profane, provocative and inventive - are to be preferred over accessibility and bourgeois sentimentality. Boswell argues that works of Holocaust impiety 'deliberately engineer a sense of crisis in readers, viewers or listeners by attacking the cognitive and cultural mechanisms that keep our understanding of the Holocaust at a safe distance from our understanding of ourselves' (2012: 3), forcing us to acknowledge that we ourselves could have been perpetrators or bystanders in this atrocity. The important caveat in all this critical discourse, however, is that it applies to adult historical fiction about the Holocaust.

Once again, different rules apply to children's Holocaust fiction, to the extent that adult and children's Holocaust fiction seem to inhabit parallel universes. In scholarly discussions about children's Holocaust fiction, especially those carried out by educationists, there is rarely mention of the preference for experimental aesthetics as opposed to literary realism. In children's Holocaust fiction, it is acceptable to focus on individual stories; it is okay for good to triumph over evil, for redemption and meaning at the novel's end. This is because while Holocaust etiquette certainly prevails in children's fiction, children's Holocaust fiction is generally subject to yet an additional set of prescriptions shared alike by authors and educationists: 1) Holocaust fiction must be didactic and, therefore, as scrupulously accurate in its portrayal of historical facts and events as possible (there are few concessions to disquisitions about the unreliability of memory or the fictiveness of history);2) the actual events of Holocaust nevertheless need to be 'sensitively handled' because children should not be scared or traumatised by what they read; 3 ) children should be given some kind of hope to hold on to; 4) and children should be taught that they have agency - a hard task indeed when writing about Holocaust victims (see Kertzer 1999, Bosmajian 2002 and Kokkola 2003 for a critique of these assumptions). The latter two points of this list - a list we might call Children's Holocaust Etiquette - dovetail with the 'Americanization of the Holocaust', something which is critiqued in adult popular culture but applauded in children's fiction.

Kathy Lowinger perhaps expresses these ideas most clearly in her introduction to the anthology Tapestry of hope: Holocaust writing for young people (2003), a book whose very title would be extremely dubious if it were an anthology of adult writing because it contravenes the idea that hopeful, redemptive narratives undermine the history and meaning of the Holocaust and insult the experience of Holocaust victims and survivors. Because this is a children's book, however, it is unexceptionable for Lowinger to write the following:

If the Holocaust were about evil alone, it would be best to shut its memory away, and never breathe its name. But if the Holocaust is about immeasurable suffering, it is also 
about courage. If it is about despair, it is also about hope. If it is about needless death, it is also about precious life (2003: Introduction).

The general approach to children's Holocaust fiction, then, is markedly different from adult Holocaust fiction, not least because children are expected to 'enjoy' what they read so that they can learn about the Holocaust through fiction without being 'emotionally disturbed' even though they are also supposed to empathise with 'the perspective of a child who lived during the Holocaust and perhaps begin to address their own questions of what it was like and how it could have happened' (Jordan 2004: 199-200) - a paradoxical task indeed.

To what extent, then, do the acclaimed historical novels of Jackie French abide by Holocaust Etiquette, Holocaust Piety, and Children's Holocaust Etiquette? What do readers learn about the Holocaust from her novels?

\section{Jackie French's Holocaust fiction}

Jackie French is an Australian children's author who has written 140 books over a period of 25 years. Many of her books have been shorted-listed for or have won various national and international awards: literary awards, children's choice awards and the aforementioned Young People's History Prize (French 2104a). Named the Australian National Children's Laureate for 2014 and 2015 by the Australian Children's Literature Alliance, French considers herself a historian as well as a novelist (French 2014b). Her range of fictional subjects is very wide, focusing particularly on Australian history, culture and environment. Her two internationally acclaimed books - Hitler's daughter (1999) and Pennies for Hitler (2012) - attempt to knit European history into the Australian past, acquainting young readers with the difficult topic of the Holocaust.

Hitler's daughter tells the story of four schoolchildren in rural Australia who play 'The Game', making up stories they recount to each other while waiting for the school bus. One of the children, Anna, begins to tell them a story about a German child called Heidi, the secret daughter of Hitler. There is actually very little substance to Heidi's story. She calls Hitler 'Duffi' and rarely sees him because she is hidden away at Berchtesgaden where she is looked after by two women - Fräulein Gelber, a governess and Frau Mundt, a cook. She realises that her father will not acknowledge her because she has a big birthmark marring her face, and one of her legs is shorter than the other, causing her to limp. Sometimes Duffi 'brought her dolls with long blonde hair that made her cry secretly at night, because they were beautiful and she was not. If she looked like the dolls he would have let her call him Father' (1999: Location 314). Her closest relationship is to the cook, Frau Mundt, who helps her understand why Germans supported Hitler after the economic problems of the 1920s and the Depression:

he told us how he wanted to be on the side of the unemployed ... He would save us, he would get us jobs, he would make Germany proud and free again, and I was cheering 
with everyone else while the tears ran down my cheeks ... No one else promised what he did. He was the only one who gave us hope (Location 314).

From her caregivers, Heidi learns about the concentration camps and about the despised position of Jews. She sympathises with the Jews because she knows what it is like to be imperfect, and she resolves to prepare a place in the garden to hide them if she should come across any. She never does, of course; 'It was late in the war by then and they were in concentration camps and very few escaped from those' (Location 993). Eventually, Heidi leaves Berchtesgaden to join 'Duffi' in his bunker in Berlin. She tries to see him but he publicly and vehemently repudiates any knowledge of her. A German guard helps her to escape the bunker and she wanders across Berlin, currently being invaded by Russians, until a German couple called the Schmidts adopt her. After the war, they immigrate to Australia where Heidi goes to school, grows up, and eventually marries. The book ends with Anna suggesting that Heidi was actually a real historical figure who only ever told her story to one person: her granddaughter. The reader is left to infer that Anna is probably that granddaughter - the secret great-granddaughter of Hitler.

Interspersed with Anna's story about Hitler's daughter are the reflections, questions, and discussions that another child, Mark, has with his parents and his teacher. We know very little about Mark. He functions primarily as a vehicle for historical facts to be conveyed, for disturbing ethical questions to be raised, and for issues relating to the Holocaust to be connected to contemporary Australian concerns. Mark's questioning of the adults elicits historical information about the six million Jews killed, along with gypsies, trade unionists and the disabled; the Nazi attempts to breed an Aryan race; Jesse Owens winning at the Berlin Olympics and infuriating Hitler because Owens was black; and that Germany was a totalitarian country, which meant that 'Hitler controlled the radio and the newspapers, so no one was allowed to say anything he didn't agree with. And if you tried to speak out you were sent to a concentration camp' (Location 883). Mark's conversations with his father, on the other hand, connect issues of perpetrator guilt and generational responsibility to contemporary Australia when he asks his father how great-great-grandpa acquired their farm; did he steal it from the Aborigines? Mark's father angrily denies this - 'It wasn't like that in those days, anyway. No one thought of it as stealing' (Location 839) - and denounces the 'things they teach kids nowadays ... Do-gooders poking their nose in where it doesn't concern them' (Location 862), thus indirectly invoking the spectre of the Australian history wars at the turn of the twenty-first century. Finally, Mark's questions to his teacher Mr Robinson allows ethical questions about collective guilt, generational guilt, and relative morality - how people can know whether they are right or wrong - to be inserted into the text. There is, in fact, a lot of historical information and ethical or moral questions raised in Hitler's daughter, which is why the plot is rather thin and the novel preponderant with discursive dialogue.

Pennies for Hitler, on the other hand, has a much more dynamic plot and stronger characters. The book opens in 1939 on a day when Georg Marks, a patriotic young Nazi boy, is distinguished in class by being told that he has the perfect Aryan head. Rushing home to celebrate this news, his mind filled only with this triumph and 
thoughts of cream cakes, the day turns into a nightmare when his father, an Englishborn professor of German literature at the university, is tossed out the windows of the university halls, falling to his death because he tried to defend some Jewish students. The mob of university students then turn on Georg and his mother, calling them Jews because his grandfather was Jewish. Realising that Georg is no longer safe in Germany because he is now considered Jewish, his mother arranges for Georg to be secretly smuggled out of Germany and taken to England, where he will live with his aunt Miriam. He is lucky because he has an English passport since his father was English, so he can flee Germany more easily than other Jews in 1939. Georg stays with his aunt until the war breaks out and the Blitz begins in September 1940. Eventually, his aunt's wartime work for the government takes her away to the countryside and she can no longer look after him. She arranges for him to be sent to safety in Australia, where he is fostered by the Peaslakes, a family in rural Bellagong who lose their only son in the war. The rest of the novel focuses on German Georg pretending to be English George, terrified of having his secret uncovered and being rejected by his new family and friends, and finally realising that his Australian family and the Bellagong community do not regard him as the enemy but, rather, are eager to extend love and compassion to this traumatised young German-Jewish-English boy. The novel concludes with the war ending, and Georg being reunited with his mother, who has survived the war and who immigrates to Australia as a Displaced Person.

As with Hitler's daughter, Pennies for Hitler manages to pack in a fair bit of historical information. Readers learn the following about the Holocaust: the Nazi pseudoscience of craniometry practised at schools; Nazi anti-Semitism and antiJewish propaganda; Kristallnacht, 'when the Brown Shirts had risen up against the Jews, burning their houses, smashing their shops, painting the big yellow Star of David on their doors so they couldn't pretend to be like everyone else' (French 2012: 8); why the Germans supported Hitler and discriminated against Jews - 'Germany was in a bad way when [Hitler] came to power. And he's done good things - bringing the nation together again. But to do that he blamed all the hardships on the Jews, creating hatred and fear, to give communists and fascists and every unemployed peasant a common enemy. The Jews' (63); and why the Jews were trapped in Germany and Austria - 'Ten thousand Jewish women marched through the streets of a place called Palestine to ask the English rulers to let more Jews come from Germany to Palestine. But it seemed the Führer wouldn't let them out, nor the English rulers let them in' (71).

Basic facts about the outbreak of the Second World War and the British experience are also recounted: the Pact of Steel signed between Hitler and Mussolini on 22 May 1939; the Nazi-Soviet Non-Aggression Pact of 23 August 1939; Operation Pied Piper - the evacuation of children out of London to the countryside and Wales in preparation for bombing raids; rationing; the Phoney War; the evacuation of Dunkirk; Churchill's speeches; and the experience of air raids and sheltering in the London Underground. The experience of war in rural Australia is relatively peaceful, but there is also mention of the fear of the Japanese invasion with Japanese submarine raids off 
the coast and air raids over Darwin, and the novel shows what it is like for a family to lose a loved one in the war.

According to the NSW Young People's History Prize judges, Pennies for Hitler won the history prize because it

gives a complex rendering of life in the Battle of Britain and of the experiences of a Jewish refugee, and immerses young readers in a variety of lesser known experiences of war. These include the transportation of unaccompanied children, the difficult position of German dissenters and the induction of women into high-level government work. Georg constantly crosses boundaries - of territory and of enmity — and, in the process, invites young readers to experience the dissolution of hate into kindness (NSW State Library 2013).

This latter point is an important value that French herself emphasises.

French notes that Pennies for Hitler is connected to Hitler's daughter because it comes from the same rudimentary source material: stories told in her childhood by a former concentration guard camp,

the whispered memory of a friend's father, who had watched his fellow students thrown out a high window at a graduation day by a band of Nazis; the oral history of a Jewish boy who was told he had the 'most Aryan head' in the whole class; a neighbour who had escaped Nazi persecution in Germany as a small child, but then become a German enemy in England, finally - unexpectedly - discovering love and happiness in Australia (2012: 'Further note from the author').

But French writes that Pennies for Hitler also originated from a letter written to her by a fourteen-year-old boy who was in a class for the intellectually handicapped, and who had seen the dramatised version of Hitler's daughter: The play, then read the book. The boy simply wrote to her: 'What I have learned from your book is to be very wary of anyone who tries to make you angry. Yours, James' ('Further note'). French concludes: 'I had never realised that message was in Hitler's daughter, but perhaps it's the most important one there is.' Pennies for Hitler is thus a book about 'about a boy who isn't there, who can't be anywhere, because wherever he goes he is the enemy. It is about how hatred is contagious, but it is also about how kindness and love and compassion are contagious too' ('Further note').

On the whole, the two novels adhere to the various prescriptions for representing the Holocaust in historical fiction. They treat the Holocaust as a serious, significant topic that all children should learn about, but readers are mostly shielded from actual depictions of violence. Apart from Georg's father being flung to his death, Georg fearing that the ship transporting him to Australia will be blown up by German submarines, and Heidi encountering dead bodies as she makes her way across Berlin, death remains rather abstract for the most part. This concern to treat the Holocaust 'sensitively' and spare the child reader fear, grief and trauma not only fulfils the requirements of Children's Holocaust Etiquette, but also of Holocaust Piety. The experience of the camps themselves remains unrepresented, unrepresentable. Because of this, children never really come to grips with trying to understand how and why the 
Holocaust occurred. They learn that Jews were discriminated against because Germans were 'afraid' and 'angry'; they wanted, and Hitler gave them, a common enemy to blame. But we never learn the historical reasons for German and other European anti-Semitism, or come face to face with genocide. Physically, as well as metaphorically, the child protagonists at the heart of the Holocaust stories - Heidi and Georg - are hidden away and then transported out of Germany without fully understanding the magnitude of what they are escaping. Admittedly, society at the time, let alone the child victims of these novels, could not be expected to know or understand more, so the limited explanations offered in these novels are no doubt realistic.

Children's Holocaust Etiquette is also fulfilled because the novels emphasise the moral agency of children. Heidi wants to help the Jews and later, with the help of the guard in the bunker, she rescues herself by walking away from her 'Duffi'. Georg looks after himself as he is transported across Europe and then halfway across the world to Australia. He also makes the moral choice not to kill an injured pilot who drops from a plane and whom he believes to be Japanese. And, of course, the stories are hopeful and ultimately redemptive. They leave children with hope because Heidi survives and immigrates to Australia, where she gets educated, married and has a family, while Georg is reunited with his mother in Australia at the end. Australia is thus the endpoint of Holocaust suffering and the setting for redemption. Hitler's daughter disturbs this equation more than Pennies for Hitler, because Mark keeps trying to correlate perpetrator guilt and generational responsibility with the Australian appropriation of Aboriginal land. This comparison actually subverts Holocaust Etiquette Rule 1: that the Holocaust be treated as a sacred, unique event cordoned off from all other history or historical comparisons. But it is an unavoidable move in children's historical fiction because, in the words of American children's author and educationist Valerie Tripp, 'what we're trying to do through historical fiction is to help our students realize they are what history is. What they do matters ... What we're trying to do is to sort of tickle a moral intelligence, a mindfulness, a sense of responsibility, into being' as children 'use themselves and their own lives as comparisons to the characters that lived long ago' (2011). Thus French's novels also invite 'young readers to experience the dissolution of hate into kindness', and it is for the portrayal of moral agency and redemptive narrative that the judges awarded Pennies for Hitler the prize, not merely for its didactic historical content.

As far as historical factuality is concerned, Pennies for Hitler is the more accurate of the two, providing names, dates of events and quotes from Churchill in painstaking detail. The extensive Author's Notes explains the historical background to events in the book, distinguishing between which parts are based on historical evidence and which parts are fictitious, noting disagreements in interpretation among historians over the imminence of the Japanese invasion of Australia, and including two wartime recipes. By contrast, Hitler's daughter is rather vague in the historical facts it provides, hampered by the strategy of feeding historical information through the questions children ask adults and each other. The blinkered knowledge and limited understanding of Heidi and her caregivers hinder this process, as does the studied 
ignorance, indifference and discomfort the adults around Mark display when confronted with his questions about Hitler and the Holocaust as well as the "lessons of history' for contemporary Australia. There is no Author's Notes section at the end of Hitler's daughter to provide readers with clarification about fact and fiction, or further historical information.

This is, in fact, one of the problems of using Hitler's daughter, in particular, as a source of historical understanding of Nazi Germany, Hitler, the Second World War and the Holocaust. Just as Mark in the novel becomes confused over what is true and what is not, so too have some readers experienced that same confusion. Mark becomes increasingly perplexed over how to respond to Anna's story: 'It was only a story ... Just a story, nothing more. It wasn't true - but there were true things in it. Maybe that's what puzzled him' (1999: Location 433). Such ideas, remarkably, echo poststructuralist metahistorical critiques of history claiming to be a more accurate account of the past than fiction - as discussed above. Some readers, especially younger ones, appear to be confused about what actually took place in the past, and what was made up. On a Goodreads.com forum, LE Mar wrote that 'The end of Hitler's Daughter subtly implies that there is a truth behind the fictional tale of Heidi. A lot of young people I've known who read the book have been confused and wondered if Hitler really did have a daughter'. Another reader drew a comparison between the conspiracy theory of Dan Brown's The Da Vinci code and the theory that Hitler had a secret daughter. Fact slides easily into fantasy and then into plausibility in historical fiction if there is not already prior knowledge of the history in question.

In the concluding section of this paper, I will look briefly at reader responses to these two novels from Amazon.com, Amazon.co.uk and the website Goodreads.com, which contain some of the most extensive reviews of the two books by readers (URLs are provided in the references below). There are obvious limitations to such an exercise. The reviews are generally written by those readers who were enthused enough by the book to leave their thoughts about it (unless they were made to do this as part of a class assignment, as appears to be the case with some reviews on the Amazon.com site), and the majority of these reviews skew heavily towards Americans, which is sometimes problematic since French is writing primarily for Australian children and some American children appear bored by the Australian scenes. However, the crosscultural appeal of French's novels is shown by the fact that there are far more positive reviews of her books by readers of all ages and backgrounds than critical comments. Obviously, the use of online reader reviews to gauge such issues in this paper is only a start to understanding how people read and engage with history and historical fiction. What we really need are more targeted surveys and reader interviews that take readers' various backgrounds into account. With this caveat in mind, however, some tentative conclusions can be drawn about what readers learn from these novels and how they respond to the Holocaust.

There are more reviews of Hitler's daughter on Amazon.com than Pennies for Hitler because Hitler's daughter won the American Bulletin for the Center of Children's Books' Blue Ribbon award and seems to have been assigned for elementary school reading, and Pennies for Hitler was also published more recently. On the whole, 
readers who reviewed the books on all three websites loved French's novels, usually giving her four or five stars out of five. The ones who are the most enthusiastic about the novels appear to be adult readers, especially parents, teachers and librarians, but almost all the self-identified 'kid reviewers' on the Amazon.com site also liked both novels very much. Reviewers generally agreed that the books were aimed at ten-totwelve year olds but added that adults would also enjoy them. What adults enjoyed most was not only the story itself, but also the opportunities to discuss 'thoughtprovoking questions' in a classroom setting or with their children. The ethical issues and historical questions raised by French were the focus of commentary, rather than the historical background of the novel. For example, $M$ Dijkstra from The Netherlands wrote on the Amazon.co.uk site that 'The story about Hitler's daughter raises all kinds of questions in the children who listen to it, e.g. are you responsible for your parents' acts? What would you do if your parents acted evilly? I found this aspect of the book very interesting.' Dijkstra highly recommended the book to other adults. Young readers similarly enjoyed being intellectually stimulated by these moral, ethical and historical hypothetical questions. Robert Solomon, who was assigned the book in an American elementary school, wrote that Hitler's daughter 'covers more mature themes which I enjoyed greatly when I read it. It made me feel adult and insightful and it made me question the world around me.'

The Goodreads reviewers focused more on the historical aspects of Hitler's daughter than the Amazon reviewers, although there were those on Goodreads like Pamela Lloyd who wrote:

The more I think about this book, the better I think it is. The issues are very real and very much a part of what we all must deal with. All of us would do well to revisit questions about the issues and feelings, because this book isn't so much about Hitler, as about right and wrong, and how we develop our understanding about what they are.

Self-described 'kid reviewers' on the Amazon.com site seemed to enjoy Hitler's daughter more than those on Goodreads.com, where most of the enthusiastic reviews seemed to come from adult readers (judging by level of literacy, since not as many self-identify as young reviewers on Goodreads). While most young readers were very enthusiastic about Hitler's daughter for its historical content as well as the ethical issues raised for them to consider, there were also a few who did not enjoy it. One reviewer, who read it on the recommendation of the school librarian, disliked it because 'at some level I felt as if my intelligence was being insulted. These were books that adults chose because they thought they were good for children. In reality they were overly sentimental, simplistic and unrealistic.' This comment is fascinating because it dovetails in some ways with literary critics' censure of straightforward, sentimental Holocaust stories that do not employ either modernist aesthetics or Holocaust impiety to shock, disturb or destabilise the reading experience. This comment, coupled with Robert Solomon's above, also shows that there are other elements at play in how children read novels, such as the desire to feel 'adult' and not patronised as children. Other readers who disliked the book were simply bored by the lack of plot and the flatness of the characters who, in the words of Mikaela Ripley, 'are hard to connect to, which makes the book just paragraphs of words.' 
Recommendations by librarians seem to provoke particular ire when the book disappoints, as in Lauren H's comment:

the author was from Australia and doesn't have any background knowledge. She could have done more research and made it seem more realistic. I recommend this book to anyone who cannot comprehend and take in a plot and wants a book with no climax at all! This book is one of the worst books I have read and in my opinion Ms Ozburn should take it out of her library as it has no facts or real information at all.

Similarly, Sam Parry (who thought the book was set in Austria rather than Australia) opined:

The theme in this book can be touching, worthwhile, and sad. The characters are hard to connect to and they are very annoying ... This book makes you feel sad for those who were affected by the Holocaust. If you are looking for a boring WWll book with no plot, then this is the book for you!

As for Pennies for Hitler, the vast majority of readers very much enjoyed the book, especially those who reviewed it on the Amazon.com site (there were no reviews on Amazon.co.uk). Clare Cannon's review typifies the perspective of the majority when she commended the book for being 'realistic historical fiction without melodramatic action or adventure for entertainment's sake; it presents challenges that people were called to live through, and which, with great strength of character and edifying equanimity of soul, they did live through.' The average reader's requirement of hope, optimism and redemption even, or perhaps especially in a Holocaust novel comes through in these words, and that may be one of the reasons why adult readers respond so enthusiastically to these books. They are allowed these feelings in children's Holocaust fiction in ways that may be suspicious in adult Holocaust fiction because of some awareness of 'Holocaust Etiquette', however vague, and because the modernist literary aesthetic in adult fiction is slanted towards the pessimistic, with 'happy endings' regarded as sentimental, 'middle-brow' and, hence, 'bad' fiction. Yet adult readers, as much as children, want to feel 'moved'. Kaysey, who read the book together with her over-fifty book club, liked how 'George lives in the fear his German heritage will be discovered but ... he finds acceptance and love in the family and the community where he lives. It is a very moving book, and one I would recommend to all readers, young and not so young.' Again, Goodreads reviewers had a greater mix of enthusiastic, slightly sceptical and more critical responses than Amazon reviewers. The most enthusiastic were the ones who 'learned' the inspiring moral lessons of the book: 'facing loss and suffering on the strength of love; relying on the goodness of strangers; friendship and the love of family'; learning that 'being German does not make you a Nazi, just as Georg learns that looking Asian does not mean you are a Japanese, and that saving life is above national barriers.' From this last quote, however, one might question what kind of historical or moral lessons have been learned? The Japanese seemed to be homogenised in the very same sentence that Germans are differentiated as individuals. The thinking of this reader on the subject clearly remains quite muddled even though the point about tolerance and not discriminating against others has been grasped. Those who did not like Pennies for 
Hitler tended to be children assigned the book at school, and their critical reviews are fairly predictable. Emilyzzz was one of these forced to read the book 'by my stupid school':

I have to say I don't like war books, they're just not my thing and the beginning of this book did not help my view of them. Georg was a complete idiot ... All he cared about were cream-cakes and having the perfect 'Aryan' head. He'd just seen multiple people tossed out a window to their deaths, including his own father, and as he and Mutti (his mum) were running for their lives he wanted to stop and grab a cream-cake! Seriously?! ... I hated it so much I envisioned sticking the book in the fire and watching it burn.

Whatever historical lessons Emilyzzz learned from this novel, clearly the connections between book-burnings and the Holocaust were not among them.

What do these reviews, with all their limitations, tell us about French's novels as historical fiction touching on the Holocaust? They confirm the view that the Holocaust is such a special and unique event in history that schoolchildren must learn about it somehow, and that children's historical fiction is considered an excellent way of drip-feeding this knowledge; that the Holocaust 'must be approached as a solemn and even sacred event, with a seriousness' (Des Pres 1988: 278) not only about Holocaust history, but about the universal moral and/or ethical questions it raises. The Holocaust cannot just be about history, it must also be about profound 'issues' and moral lessons. The reviews show that Children's Holocaust Etiquette - particularly the requirements of hope and agency - is appreciated as much by adults as by children, and that may indeed be why some adults are reading children's Holocaust fiction rather than more nihilistic, despairing, technically difficult and unsettling adult fiction. And they also show, in some ways, the limitations of Holocaust fiction in conveying the facts of Holocaust history to independent readers. Reviewers who selfidentify as young readers or who come across as such because of the level of their literacy skills and idiom do not appear to take in very much historical information apart from very basic facts. Those who got most out of the books needed to be guided by discussions with parents, teachers or librarians, but these were often the very readers who turned discussion away from history (of which they perhaps had limited knowledge, just like Mark's parents) and towards universal lessons or questions of virtue, character, morality, sentiment and behaviour instead. Both novels actually fulfil Valerie Tripp's criteria for 'good historical fiction'; that is, fiction which

exercises a child's imagination through a vicarious experience. It leads children to use themselves and their own lives as comparisons to the characters that lived long ago and often, far away, to reflect on their own experience, to ask their families questions. It awakens awareness, perks up perception, sparks conversations. Reading historical fiction can lead a child to ask, 'What's $m y$ voice? What's $m y$ view? Which side should I be on? Is there a right side?' (original emphasis)

Both novels lead the reader to empathise with characters in the past. What the reader appears to gain most, however, is self-knowledge rather than historical knowledge and understanding. 
Lydia Kokkola raises this concern in her study of the Holocaust in children's literature. Despite the copious research and careful attention to historical detail that novelists undertake, historical understanding of the Holocaust is ultimately constrained by authors' and educationists' views about Children's Holocaust Etiquette and, increasingly, on the emphasis on self-understanding rather than understanding history or historical interpretation, resulting in 'texts that are politically correct, but historically inaccurate, or that "spare the child" to such an extent that they are misleading' (2013: Location 4094). Kokkola concludes that 'it is simply untenable to expect literature to lead children to understanding in the same ways that one would expect nonfiction works ... "Understanding" the Holocaust as a historical fact and "understanding" fictional characters are different kinds of activities' (Location 4232). This is not to discount the value of children's Holocaust fiction, but historical novels are best read and enjoyed as fiction, with appreciation for the author's meticulous attention to historical research and detail as well as literary craftsmanship. Kokkola argues that 'expecting novels to function as a kind of historical text book of the period will at best cause genre confusion, at worst result in the presentation of distortions of history' (Location 4251).

Nonetheless, we have a chicken-and-egg situation where historical knowledge and children's historical fiction is concerned. If the historical novel is supposed to impart knowledge and understanding about the past, and to help readers understand causation, choices, and motivations, then the reader reviews - for all their limitations - seem to suggest that children (and no doubt many adults also) learn best from novels when they already have some background knowledge about the historical subject or are guided by teachers or parents who discuss the novels in conjunction with nonfiction history texts, as Kokkola argues. They are otherwise prone to mixing up fact and fiction, such as whether Hitler had a secret daughter. But the reader reviews also suggest that readers are most enthused to discover more about a historical subject after they have connected with it through the imagination and the emotions, identifying with the lives of individual characters (although this is problematic in itself - see Eaglestone 2004: 101-36) and then finding out more about the era in which the novel was set. This is precisely the reason why the NSW Premier's Young People's History Prize can be awarded to novels. It is a prize that encourages curiosity and further exploration of the past. I am by no means arguing that history prizes should be awarded to adult historical fiction; merely inviting us to consider why adult historical fiction should be evaluated with such different standards and expectations.

The debates over history and historical fiction ultimately beg the questions: how much about the past do we expect the general public to know and understand? At what point is historical knowledge 'good enough'? And how do we get people to care about the past? We do not expect children to swallow wholesale and in one gulp everything important there is to know about, say, the Holocaust. We accept that children initially apprehend history piecemeal, fragments of knowledge are later added, and understanding increasingly fine-tuned. Rather like a painting where the lineaments of the subject are roughly sketched, then blocks of colour laid down, and various details increasingly added until a rich picture emerges. Initially learning about the past 
imperfectly, through historical fiction, is therefore acceptable for children, and so is identifying with fictional characters and being moved by a story. But these things do not appear to be acceptable for adults, certainly not for adult historical fiction which is so often accused of being historically inaccurate. Even those who would defend adult historical fiction do so on the grounds that history is disingenuous as to its claims about the past, and that historiographic metafiction, in particular, is more 'truthful' in problematising what can be known about the past (Southgate 2009). Moreover, the historical fiction referred to by historiographers and literary critics is often literary fiction, difficult fiction, because fiction that is easy to read, too moving, is suspicious; it is too enjoyable. Is there some underlying assumption that enjoyment and accessibility are fine for children, but History - particularly Holocaust history - must be hard work for adults? That in adulthood, it is time to put away childish things, and to know, not merely in part, but in full? That what is good enough for children cannot be good enough for adults? I suspect this might be the next conversation we need to have about history and fiction.

\section{Endnote}

1. Yad Vashem is Israel's official memorial museum and research institute into the victims of the Holocaust.

\section{Works cited}

Adorno, Theodor 1967 'An essay on cultural criticism and society', in Prisms, Cambridge, Mass: MIT Press, 17-34

Amazon.co.uk nd 'Review of Hitler's daughter), http://www.amazon.co.uk/Hitlers-Daughter-JackieFrench/product-reviews/0007122721/ref=sr_1_1_cm_cr_acr_img?ie=UTF8\&showViewpoints=1 (accessed 16 October 2014)

Amazon.com nd 'Review of Hitler's daughter', http://www.amazon.com/Hitlers-Daughter-JackieFrench-ebook/product-reviews/B0042JSPOS/ref=pr_all_summary_cm_cr_acr_txt? ie=UTF8\&show Viewpoints $=1 \&$ sortBy=bySubmissionDateDescending (accessed 16 October 2014$)$

Amazon.com nd 'Review of Pennies for Hitler', http:/www.amazon.com/Pennies-Hitler-Jackie-French -ebook/product-reviews/B00760GD08/ref=sr_1_1_cm_cr_acr_txt?ie= UTF8\&show Viewpoints=1 (accessed 16 October 2014)

Bosmajian, Hamida 2002 Sparing the child: Grief and the unspeakable in youth literature about Nazism and the Holocaust, New York: Routledge

Boswell, Matthew 2012 Holocaust impiety in literature, popular music and film, Houndsmill: Palgrave Macmillan

Browning, Christopher R 1992 Ordinary men: Reserve Police Battalion 101 and the Final Solution in Poland, New York: Aaron Asher Books

Curthoys, Ann and John Docker 2010 Is History Fiction?, Sydney: UNSW Press

Des Pres, Terrence 1988 'Holocaust laughter?', in Berel Lang (ed) Writing and the Holocaust, New York and London: Holmes \& Meier, 216-33

Eaglestone, Robert 2004 The Holocaust and the postmodern, Oxford: Oxford University Press

Evans, Richard 1999 In defence of history, New York: WW Norton 
Franklin, Ruth 2011 A thousand darknesses: Lies and truth in Holocaust fiction, Oxford: Oxford University Press

Freeman, Evelyn 1988 'Recreating the past: Historical fiction in social studies curriculum' The Elementary School Journal 88:4, 23-33

French, Jackie 1999 Hitler's daughter, Sydney: HarperCollins (Kindle DX)

French, Jackie 2012 Pennies for Hitler, Sydney: HarperCollins

French, Jackie 2014a 'Welcome to the world of Jackie French: Award winners', http://www.jackiefrench.com/beta/pages/awards.html (accessed 16 October 2014)

French, Jackie 2014b “'Welcome to the world of Jackie French: News', http://www.jackiefrench.com/beta/pages/index.html (accessed 16 October 2014)

Frye, Northrop 1957 Anatomy of criticism, Princeton, NJ: Princeton University Press

Ginzburg, Carlo 1992 'Just one witness', in Saul Friedlander (ed) Probing the limits of representation: Nazism and the 'Final Solution', Cambridge, Mass: Harvard University Press, 82-96

Goodreads.com nd 'Reviews of Hitler's daughter', http://www.goodreads.com/book/show/1157924.Hitler_s_Daughter?from_search=true (accessed 16 October 2014)

Goodreads.com nd 'Reviews of Pennies for Hitler', http://www.goodreads.com/book/show/13609403pennies-for-hitler (accessed 16 October 2014)

Herz, Sarah K 2010 'Using historical fiction in the history classroom', Yale-New Haven Teachers Institute, http://www.yale.edu/ynhti/curriculum/units/1981/cthistory/81.ch.10.x.html (accessed 8 October 2014)

Hicks, Alun and Dave Martin 1997 'Teaching English and history through historical fiction' Children 's Literature in Education 28:2, 49-59

Hutcheon, Linda 1988 A poetics of postmodernism: History, theory, fiction, New York: Routledge Jenkins, Keith 1991 Re-thinking history, London and New York: Routledge

Jordan, Sarah D 2004 'Educating without overwhelming: Authorial strategies in children's Holocaust literature' Children's Literature in Education 35:3, 199-218

Kertzer, Adrienne 1999 “'Do you know what 'Auschwitz' means?” Children's literature and the Holocaust' The Lion and the Unicorn 23:2, 238-56

Kokkola, Lydia 2003 Representing the Holocaust in children's literature, New York: Routledge (Kindle DX)

Langer, Lawrence L 1975 The Holocaust and the literary imagination, New Haven: Yale University Press

Lanzmann, Claude 1995 'The obscenity of understanding: An evening with Claude Lanzmann', in Cathy Caruth (ed) Trauma: Explorations in Memory, Baltimore: Johns Hopkins University Press, 20020

Lowinger, Kathy 2003 'Introduction', in Lillian Boraks-Nemetz and Irene N Watts (eds) Tapestry of hope: Holocaust writing for young people, Toronto: Tundra Books (Ebook)

Macfie, Alexander 2012 'Keith Jenkins retrospective' Reviews in History 1266 http://www.history.ac.uk/reviews/review/1266 (accessed 8 October 2014)

Norton, Donna 1999 Through the eyes of a child: An introduction to children's literature, New Jersey: Prentice-Hall

NSW State Library 2013 'Young People's History Awards 2013', http://www.sl.nsw.gov.au/about/awards/premiers_awards/nsw_premiers_history_awards/2013_nsw_pr 
emiers_history_awards/2013_pha_shortlist/2013_young_people\%27s_history_awards.html (accessed 6 February 2014)

NSW State Library 2014 'NSW Premier's History Awards 2014 Guidelines', http://www.sl.nsw.gov.au/about/awards/docs/2014_nsw_premiers_history_awards_guidelines.pdf (accessed 14 July 2014)

Parrish, Timothy 2008 From the Civil War to the apocalypse: Postmodern history and American fiction, Amherst: University of Massachusetts Press

Rodwell, Grant 2013 Whose history: Engaging history students through historical fiction, Adelaide: University of Adelaide Press

Rose, Gillian 1996 Mourning becomes the law: Philosophy and representation, Cambridge: Cambridge University Press

Rosenfeld, Alvin H 1997 'The Americanization of the Holocaust', in Alvin H Rosenfeld (ed) Thinking About the Holocaust: After Half a Century, Bloomington: Indian University Press, 119-150

Southgate, Beverley 2009 History Meets Fiction, New York: Longman

Tripp, Valerie 2011 'Vitamins in chocolate cake: Why use historical fiction in the classroom?' TeachingHistory.org National History Education Clearing House, http://teachinghistory.org/nhecblog/24679 (accessed 16 October 2014)

Vice, Sue 2000 Holocaust fiction, London and New York: Routledge

White, Hayden 1973 Metahistory: The historical imagination in nineteenth-century Europe, Baltimore: Johns Hopkins University Press

White, Hayden 1978 'The historical text as literary artefact (1974)', in The tropics of discourse, Baltimore and London: Johns Hopkins University Press, 81-100

Wiesel, Elie 1995 'A plea for the dead', in Lawrence L. Langer (ed) Art from the ashes: A Holocaust anthology, New York: Oxford University Press, 138-52

'Writing historical novels: Historical novelists on writing historical novels', http://writinghistoricalnovels.com (accessed 8 October 2014)

Yad Vashem 2015 'The Holocaust: Definition and Preliminary Discussion', http://www.yadvashem.org/yv/en/holocaust/resource_center/the_holocaust.asp (accessed 29 January 2015)

Yerushalmi, Yosef Hayim 1982 Zakhor: Jewish history and Jewish memory, Seattle: University of Washington Press 